\title{
PERAN KADER DALAM PEMANFAATAN APOTEK HIDUP DI DESA KARRANG KECAMATAN CENDANAKABUPATEN ENREKANG
}

\author{
Role of Cadre in Utilization Living Pharmacy in Karrang Village \\ Cendana District Enrekang Regency
}

Sukma, Ramlan, Makhrajani Majid

Program Studi Kesehatan Masyarakat Fakultas Ilmu Kesehatan Universitas Muhammadiyah

Parepare (sukmacs9@gmail.com)

\begin{abstract}
ABSTRAK
Apotek hidup merupakan suatu tempat yang berisikan berbagai tanaman obat yang ditanam di dalamnya yang bermanfaat untuk keperluan sehari-hari dan pengobatan. Disebut tanaman obat karena tanaman ini mengandung berbagai manfaat khasiat yang berguna bagi pengobatan suatu penyakit. Peran kesehatan dalam hal ini merupakan salah satu faktor yang sangat mempengaruhi perubahan perilaku masyarakat untuk memanfaatkan apotek hidup. Pemanfaatan pekarangan rumah dengan hijauan tanaman dalam bentuk taman merupakan prinsip hidup yang telah membudaya bagi masyarakat untuk kembali ke alam (back to nature). Tujuan penelitian ini adalah untuk mengetahui peran kader dalam pemanfaatan apotek hidup berdasakan sikap dan tindakan di Desa Karrang Kecamatan Cendana Kabupaten Enrekang. Metode penelitian yang digunakan adalah metode penelitian deskriptif survey dengan pengambilan sampel menggunakan teknik Nonprobability yaitu sempel jenuh atau sering disebut total sampling sehingga dalam penelitian ini populasi sebagai sampel. Metode ini merupakan suatu metode penelitian yang digunakan dengan tujuan utama untuk membuat gambaran atau diskripsi tentang suatu keadaan secara objektif. Sasaran penelitian yaitu kader kesehatan sebanyak 15 orang di Desa Karrang Kecamatan Cendana Kabupaten Enrekang. Adapun waktu penelitian ini dilaksanakan pada Juli sampai Agustus 2018. Hasil penelitian menunjukkan peran yang baik oleh kader kesehatan dalam pemanfaatan pekarangan untuk penanaman tanaman obat yang terlihat dalam sikap dan tindakan kader dengan $100 \%$ baik. Sebaiknya, tanaman apotek hidup lebih dilestarikan, agar anak cucu kita merasakan nikmatnya obat-obat. Rawatlah apotek hidup yang tumbuh di sekitar kita, bersihkan dari gangguan hama ataupun tumbuhan lain yang merugikan. Karena, apotek hidup adalah salah satu jenis tanaman obat, maka gunakanlah sesuai penyakit yang diderita.
\end{abstract}

Kata kunci: Pemanfaatan apotek hidup, sikap, dan tindakan

\begin{abstract}
A living pharmacy is a place that contains various medicinal plants that are planted in it which are useful for daily needs and treatment. Called medicinal plants because these plants contain various benefits that are useful for the treatment of a disease. The role of health in this case is one of the factors that greatly influence changes in people's behavior to utilize living pharmacies. The use of home yards with forage plants in the form of gardens is a principle of life that has been entrenched for the community to return to nature (back to nature). The purpose of this research was to determine the role of cadres in the use of living pharmacies based on attitudes and actions in Karrang Village, Cendana District, Enrekang Regency. The research method used is descriptive survey research method with sampling using Nonprobability technique, which is saturated or often called total sampling so that in this research, the population is sampled. This method is a research method that is used with the main objective to make an overview or description of a situation objectively. The research target is 15 health
\end{abstract}


cadres in Karrang Village, Cendana District, Enrekang Regency. The time of this research was carried out from July to August 2018. The results showed a good role by health cadres in the utilization of the yard for the cultivation of medicinal plants that were seen in the cadres' attitudes and actions with 100\% good. Instead, living pharmacy plants are more conserved, so that our children and grandchildren feel the pleasure of medicine. Take care of living pharmacies that grow around us, clean them from pests or other harmful plants. Because, the living pharmacy is one type of medicinal plant, then use it according to the illness.

Keywords: Living pharmacy utilization, attitude, and action. 


\section{PENDAHULUAN}

Kader merupakan orang terdekat yang berada ditengah-tengah masyarakat yang diharapkan dapat memegang pekerjaan penting khususnya setiap permasalahan yang berkaitan dengan kesehatan. Kader adalah tenaga sukarela yang berasal dari tokoh masyarakat sekitar dan mendapatkan kepercayaan dari masyarakat setempat merasa terpanggil untuk melaksanakan, mengembangkan kegiatan yang tumbuh ditengah-tengah masyarakat. ${ }^{1}$

Peran kesehatan dalam hal ini merupakan salah satu faktor yang sangat mempengaruhi perubahan perilaku masyarakat. ${ }^{2}$ Peran kader kesehatan dalam promosi kesehatan adalah sebagai advocator, educator, motivator dan fasilitator. Melalui promosi kesehatan akan terjadi perubahan pada tingkat sikap, serta perilaku. ${ }^{3}$

Dalam Undang-undang Kesehatan RI No.36 Tahun 2009 pasal 100 menjelaskan bahwa sumber obat tradisional yang sudah terbukti berkhasiat dan aman digunakan dalam pencegahan, pegobatan, perawatan, dan pemeliharaan kesehatan tetap dijaga kelestariannya. ${ }^{4}$

Pemanfaatan pekarangan rumah dengan hijauan tanaman dalam bentuk taman merupakan prinsip hidup yang telah membudaya bagi masyarakat untuk kembali ke alam (back to nature), sehingga suasana rumahnya menjadi asri dan alami. Sebenarnya sudah sejak lama masyarakat Indonesia mengenal berbagai taman dipekarangan atau halaman rumahnya seperti taman bunga, taman gizi dan karangkitri atau apotik hidup. Taman karangkitri atau taman apotik hidup sebenarnya merupakan cikal bakal dari apa yang dikenal saat ini yaitu Tanaman Obat Keluarga (TOGA). ${ }^{5}$

Lebih dari 1000 spesies tanaman obat di Indonesia sebagian besar belum teridentifikasi secara ilmiah. Hampir semua daerah di Indonesia memiliki tanaman obat yang telah dibuktikan kemanjurannya secara empiris. Upaya peningkatan kesehatan masyarakat perlu terus dilakukan guna mewujudkan kesejahteraan penduduk yang masih beragam. Dengan demikan pelayaan kesehatan kepada masyarakat, terutama bagi yang berpenghasilan menengah kebawah perlu terus diupayakan. Namun kendalanya adalah harga obat-obatan sekarang ini adalah cukup mahal dan tidak terjangkau bagi masyarakat meskipun tinggal di perkotaan namun masih ada warga yang kondisi ekonominya lemah. Oleh karena itu, adanya obat herbal merupakan alternatif solusi yang dapat disarankan. Obat-obat herbal tersebut dapat disediakan (berasal) dari tanaman obat yang cukup banyak tersedia di perkotaan. ${ }^{6}$

Berdasarkan hasil penelitian yang dilakukan oleh Musawwir B. 2011 dalam pemanfaatan apotek hidup di Desa Kadidi Kabupaten Sidrap yaitu kader telah menunjukkan peran yang baik dalam pemanfaatan pekarangan rumah untuk penanaman tanaman obat. Hal ini terlihat dalam hasil penelitian sikap kader secara keseluruhan sangat baik dalam pemanfaatan apotek hidup. Tindakan kader kesehatan dari 12 orang semuanya memiliki tindakan yang 
baik dalam pemanfaatan apotek hidup. ${ }^{7}$ Berdasarkan letak geogafi Desa Karrang memiliki wilayah terluas sekitar 21, $68 \mathrm{KM}^{2}$ . Banyaknya rumah di Desa Karrang yaitu sebanyak 247 rumah dan yang memanfaatakan pekarangan rumah sebagai tanaman obat yaitu sebanyak 227 rumah. Jadi sebagian besar masyarakat yang ada di desa Karrang sudah memanfaatkan pekarang dengan baik. Dengan berkembangnya Apotek Hidup di Desa Karrang, juga karena adanya partisipasi Kader dengan cara melakukan sosialisasi, penyuluhan mengenai apotek hidup, serta terjun langsung melakukan penanaman tanaman obat bersama masyarakat setempat.

\section{BAHAN DAN METODE}

Metode penelitian yang digunakan adalah metode penelitian deskriptif survey dengan pengambilan sampel menggunakan teknik Nonprobability yaitu sempel jenuh atau sering disebut total sampling sehingga dalam penelitian ini populasi sebagai sampel. Metode ini merupakan suatu metode penelitian yang digunakan dengan tujuan utama untuk membuat gambaran atau diskripsi tentang suatu keadaan secara objektif. Sasaran penelitian yaitu kader kesehatan sebanyak 15 orang di Desa Karrang Kecamatan Cendana Kabupaten Enrekang.

Data Primer adalah data yang diperoleh dari wawancara dan pengisisan kuesioner, dimana terdapat pertanyaan yang berkaitan dengan sikap kader kesehatan, tindakan kader kesehatan, dan peran kader kesehatan dalam pemanfaatan apotik hidup di Desa Karrang Kecamatan Cendana Kabupaten Enrekang. Data Sekunder adalah data yang diperoleh dari instansi yang berhubungan dengan penelitian ini adalah kader dan tenaga kesehatan lainnya yang terkait dengan objek penelitian. Data yang sudah diolah dengan menggunakan system komputarisasi dengan program SPSS (Statistical Product and Service Solutions).

\section{HASIL}

Distribusi karakteristik responden berdasakan kelompok umur, pendidikan dan pekerjaan pada Tabel 1 menunjukkan distribusi responden menurut umur dari 15 responden. Kelompok umur antara 25-30 tahun berjumlah 5 orang $(33,3 \%)$, umur antara 31-36 tahun berjumlah 3 orang (20,0\%), umur antara 37-42 tahun berjumlah 5 orang $(33,3 \%)$, dan umur antara 43-48 tahun berjumlah 2 orang (13,3\%). Distribusi responden menurut pendidikan yaitu SD 3 orang $(20,0 \%)$, SMP 4 orang $(26,7 \%)$, SMA 7 orang $(46,7 \%)$, dan S1 1 orang $(6,7 \%)$. Berdasarkan golongan umur dari 15 responden yang berumur 31-36 tahun berjumlah 5 orang dan 37-42 tahun berjumlah 5 orang. Hal ini menggambarkan bahwa kader di Desa Karrang dalam pemanfaatan apotek hidup atau toga mayoritas dengan umur dewasa. Berdasarkan pendapat Notoatmodjo 2007, semakin bertambah usia seseorang semakin bijaksana dan banyak pengalaman atau hal yang telah dijumpai dan dikerjakan. ${ }^{2}$ Distribusi responden menurut pekerjaan 
yaitu PNS sebanyak 1 orang $(6,7 \%)$, wiraswasta sebanyak 5 orang $(33,3 \%)$ dan sebagian besar kader yang berprofesi sebagai Ibu Rumah Tangga (IRT) sebanyak 9 orang $(60,0 \%)$

Distribusi karakteristik responden berdasarkan kriteria sikap kader pada Tabel 2 menunjukkan bahwa dari 15 responden, jumlah responden yang termasuk dalam kriteria baik sebanyak 13 orang $(86,7 \%)$ dan yang termasuk dalam kriteria cukup sebanyak 2 orang $(13,3 \%)$.

Distribusi karakteristik responden berdasarkan kriteria tindakan kader pada Tabel 3 menunjukkan bahwa sebagian besar responden yaitu sebanyak 14 orang $(93,3 \%)$ memiliki tindakan yang termasuk dalam kriteria baik dalam pemanfaatan apotek hidup, dan yang termasuk dalam kriteria cukup sebanyak 1 orang $(6,7 \%)$. Hal ini menunjukkan bahwa tindakan kader baik dalam pemanfaatan apotek hidup di Desa Karrang Kecamatan Cendana Kabupaten Enrekang.

\section{PEMBAHASAN}

Sikap adalah suatu disposisi atau keadaan mental di dalam jiwa dan diri seseorang individu untuk bereaksi terhadap lingkungannya (baik lingkungan manusia atau masyarakatnya, baik lingkungan alamiahnya, maupun lingkungan fisiknya). Alport 1935 dalam Rusmi 2009 mengatakan bahwa sikap adalah kesiapan seseorang untuk bertindak. ${ }^{8}$

Sikap merupakan salah satu variabel penentu dalam pemilihan pengambilan keputusan, tapi bertolak belakang dengan penelitian lain yang menyatakan bahwa sikap hanya berpengaruh $1 \%$ dalam pengambilan keputusan, sedangkan 99\% ditentukan oleh faktor lain. Pengobatan tradisional lebih murah dibandingkan pengobatan medis, obat tradisional memiliki efek samping lebih sedikit, penghasilan masyarakat, pendidikan, dan asal daerah (daerah pedesaan cenderung memilih obat tradisional)

Berbagai faktor yang mempengaruhi pembentukan sikap adalah pengalaman pribadi, kebudayaan, dan orang lain yang dianggap penting. Pembentukan sikap tidak terjadi begitu saja, melainkan sikap terbentuk karena melalui suatu proses tertentu, melalui kontak sosial terus menerus antara individu dengan individu lain disekitarnya demikian pula dalam pengambilan keputusan pengobatan. Dari pendapat tersebut dapat disimpulkan bahwa sikap adalah suatu respon atau reaksi seseorang dari suatu stimulus yang diberikan dan akan mendasari seseorang tersebut untuk melakukan sesuatu atau menimbulkan perilaku.

Berdasarkan hasil penelitian diperoleh data kader yang ada di Desa Karrang Kecamatan Cendana Kabupaten Enrekang berdasarkan sikap kader dalam pemanfaatan apotik hidup yaitu kategori baik sebanyak 13 orang dan cukup sebanyak 2 orang. Hasil ini menunjukan bahwa sikap kader dalam pemanfaatan apotik hidup tergolong baik. Hal ini disebabkan karena sikap kader dalam mewujudkan perannya 
dalam memanfaatkan apotik hidup seperti memanfaatkan pekarangan rumahnya sebagai tempat penanaman tanaman obat atau apotek hidup. Tanaman obat di pekarangan rumah penduduk perlu dipelihara dengan baik sehingga masyarakat lebih mengenal jenis tanaman yang dapat dijadikan sebagai obat tradisional.

Di Desa Karrang sebagian besar pekarangan rumah warga difungsikan sebagai pekarangan dengan penanaman tanaman obat. Selain kader, masyarakat telah mengetahui manfaat tanaman obat dan hanya tanaman tertentu yang memiliki khasiat dalam penyembuhan berbagai penyakit dan tidak semua tanaman memiliki manfaat sebagai tanaman obat. Penyembuhan penyakit dapat dilakukan dengan pemanfaatan tanaman obat tradisional selain penggunaan obat kimia. Usaha pengobatan melalui penggunaan tanaman obat sangat perlu dilakukan oleh masyarakat, sehingga tanaman obat dapat diramu menjadi obat tradisioanal yang dapat dimanfaatkan untuk penyembuhan penyakit bagi masyarakat.

Tanaman seperti kunyit, jahe, kumis kucing dapat ditanam di pekarangan rumah dan berguna sebagai pengusir berbagai penyakit ringan sehari-hari seperti batuk, masuk angin, dan panas dalam. Tak hanya itu, beberapa tanaman yang ada di Indonesia terbukti ampuh mengatasi berbagai penyakit yang lebih berat. Beberapa bahkan dipercaya dapat mengatasi penyakit mematikan seperti AIDS, kanker, dan sebagainya. Tanaman obat juga dapat dijadikan alternatif berobat yang lebih aman dan alami. Selain itu, tanaman obat juga baik untuk menjaga kecantikan dan kesehatan kulit dan tubuh.

Tanaman obat dapat dikonsumsi dengan cara diolah terlebih dahulu. Beberapa tanaman obat dapat digunakan sehari-hari dan diolah dengan cara sederhana seperti direbus dan dicampur dengan air atau bahan-bahan lainnya, sedangkan tanaman yang lain diolah secara modern oleh pabrik atau industri rumah tangga dengan cara dikeringkan dan dikemas dalam kemasan yang praktis untuk dikonsumsi. Kader juga sangat setuju dengan pembibitan tanaman dapat dilakukan dengan berbagai teknik. Diantaranya teknik mencangkok (air layering) tujuan pencangkokan adalah untuk mendapatkan anakan atau bibit untuk pembangunan bank klon, kebun benih klon, kebun persilangan, karena dengan teknik ini bibit yang dihasilkan bersifat dewasa sehingga lebih cepat berbunga dan berbuah. Adapun teknik sambungan (grafting) dimana teknik sambungan dilakukan dengan menyambungkan scion berupa bagian pucuk atau tunas dari tajuk pohon plus pada tanaman batang bawah dan root stock yang telah disediakan. Teknik ini akan mempertahankan sifat dewasa pohon induknya, sehingga anakan yang dihasilkan akan cepat berbunga dan berbuah.

Beberapa faktor yang mempengaruhi terjadinya perilaku, khususnya di bidang kesehatan yaitu teori Notoatmodjo 2012 dikatakan bahwa: Kesehatan dipengaruhi oleh dua faktor, yaitu faktor perilaku dan faktor non perilaku, sedangkan perilaku itu sendiri dipengaruhi 
oleh berbagai faktor yaitu faktor predisposisi, yaitu terwujudnya pengetahuan, sikap, kepercayaan, keyakinan, dan nilainilai. ${ }^{9}$ Untuk mengetahui derajat kesehatan diperlukan berbagai upaya pelayanan kesehatan yang meliputi upaya pencegahan, upaya peningkatan, upaya pengobatan, dan upaya pemulihan kesehatan yang dilaksanakan secara konprehensif.

Tindakan merupakan realisasi dari pengetahuan dan sikap menjadi perbuatan nyata. Tindakan juga merupakan respon seseorang terhadap stimulus tersebut sudah jelas dalam bentuk tindakan atau praktek tetapi tidak selalu orang yang berpengetahuannya baik langsung melakukan tindakan yang benar. Tindakan kader menunjukkan bahwa jumlah responden yang memiliki tindakan baik terhadap pemanfaatan apotek hidup sebesar 14 responden $(93,3 \%)$, memiliki tindakan cukup 1 responden $(6,7 \%)$. Berdasarkan jawaban responden, tujuan kader Desa Karrang memanfaatkan apotek hidup adalah untuk meningkatkan kesehatan, pengobatan sakit ringan, dan pengobatan rutin penyakit kronis setelah perawatan dokter.

Hasil penelitian berdasarkan tindakan kader menunjukkan bahwa tindakan kader dalam pemanfaatan apotek hidup telah melakukan dengan baik. Hal ini terlihat pada sebagian besar responden memilih kriteria baik. Ini menunjukkan kader telah memanfaatkan pekarangan untuk penanaman tanaman obat sebagai apotek hidup.
Kader kesehatan mengetahui manfaat tanaman obat. Hal ini menyebabkan sebagian besar pekarangan rumah masyarakat di Desa Karrang tidak ada yang gersang dan rata-rata dihiasi dengan tanaman obat. Selain mengetahui manfaat tanaman obat kader juga mengetahui fungsi-fungsi dari tanaman obat. Adapun fungsi dari Kunyit (Curcumadomestica) Menghentikan pendarahan, obat gatal, radang umbai usus buntu, radang rahim, keputihan, Obat sakit perut dan gangguan liver. Jambu biji (Psidium guajava) Meningkatkan trombosit dalam darah, menghentikan sakit diare/mencret. Selain mengetahui fungsi dai tanaman obat, kader menganjurkan untuk mengkonsumsi tanaman obat dan mengolah tanaman obat sehingga layak untuk dikonsumsi. Dimana salah satu tanaman obat yang baik dan layak untuk dikonsumsi yaitu kemangi dapat digunakan untuk membantu mengurangi stress. Dalam tes yang dilakukan kemangi ternyata ampuh mengurangi stress, meningkatkan adrenalin, noradrenalin dan mengurangi kadar sorotin. Peneliti di Barbara Ann Karmanos Cancer Institute Detroit, Pratima Nangia-Makker, Ph.D. mempercayakan teh daun kemangi untuk menyembuhkan masalah pencernaan dan sakit kepala. Manfaat lain dari daun kemangi adalah untuk memblok kanker payudara. Untuk mengatasi stress cobalah konsumsi ekstrak kemangi, sedangkan untuk menghindari kanker payudara Pratima Nangia menyarankan mengkonsumsi teh daun kemangi. 
Kader memberikan alternatif penyembuhan penyakit melalui pemanfaatan tanaman obat selain murah dalam kaitannya dengan biaya pengobatan juga mudah mendapatkan tanaman obat tersebut.

Tindakan kader dalam pemanfaatan apotek hidup sudah lebih baik karena kader yang ada di Desa Karrang tersebut sudah melakukan pemberian penyuluhan mengenai apotek hidup. Dengan kader memberikan contoh-contoh atau praktek-praktek yang bisa dengan cepat dicerna oleh masyarakat. Seperti halnya dengan memperlihatkan cara pengolahannya dan lain-lain seperti yang tercantum pada lampiran 4. Hal ini diupayakan untuk memotivasi masyarakat dalam pengembangan apotek hidup.

Sejalan dengan penelitian Asriullah Jabbar dkk 2016 bahwa pengobatan tradisional lebih murah dibandingkan pengobatan medis, obat tradisional memiliki efek samping lebih sedikit, penghasilan masyarakat, pendidikan, dan asal daerah. ${ }^{10}$ Selain itu, kepercayaan di Desa Sabi-Sabila terhadap penggunaan obat tradisional masih sangat tinggi. Desa SabiSabila menggunakan obat tradisional untuk penyakit ringan seperti bisul, menurunkan kolestrol dengan rebusan daun sirsak, diare dengan merebus daun jambu biji, hipertensi dengan mengkosumsi buah mentimun, alergi pada kulit akibat bakteri dengan perasan buah mengkudu, alergi makanan seperti alergi udang atau kepiting dengan meminum air kelapa merah atau perasan jeruk nipis, luka luar dengan perasan daun galing-galing, dan penyakit malaria dengan rebusan daun pepaya atau rebusan daun paria. Tindakan masyarakat pada saat sakit mereka menginginkan pengobatan yang murah dan mudah didapat sehingga mereka menggunakan pengobatan tradisional untuk mengobati penyakit yang mendadak, penyakit mendadak yang dimaksud disini adalah penyakit-penyakit mendadak yang bersifat ringan sebelum yang bersangkutan memeriksakan diri ke petugas kesehatan atau dokter.

\section{KESIMPULAN DAN SARAN}

Berdasarkan hasil penelitian yang dilakukan di Desa Karrang Kecamatan Cendana Kabupaten Enrekang selama kurang lebih 1 bulan dimulai pada tanggal 30 Juli 2018. Dapat disimpulkan bahwa kader telah menunjukkan sikap yang baik dalam pemanfaatan pekarangan rumah untuk penanaman tanaman obat. Agar pemanfaatan apotek hidup harus tetap terjaga oleh masyarakat, maka kader diharapkan dapat tetap menjaga kelestarian tanaman obat dengan tidak membiarkan pekarangan gersang, agar masyarakat yang ada di tempat tersebut ikut melakukan pemanfaatan pekarangannya. Bagi pemerintah agar dapat mensosialisasikan pemanfaatkan tumbuhan obat misalnya dengan pengembangan toga agar supaya dapat mendekatkan tanaman obat pada pelayanan kesehatan masyarakat dan merupakan salah satu langkah yang tepat untuk pelestarian tanaman obat. Hasil penelitian ini diharapkan dapat dijadikan sebagai bahan rujukan bagi peneliti 
selanjutnya dalam bidang Kesehatan Masyarakat secara umum. Sebaiknya kita dapat lebih bijak untuk memanfaatkan

\section{DAFTAR PUSTAKA}

1. Effendi, Ferry. Keperawatan Kesehatan Komunitas: Teori dan Praktik dalam Keperawatan. Jakarta: Salemba Medika.; 2009.

2. Natoatmodjo S. Kesehatan Masyarakat Ilmu dan Seni. Jakarta: Rineka Cipta; 2007.

3. Kozier. Praktik Keperawatan Profesional Konsep dan Perspektif. Jakarta: EGC; 2012.

4. Undang-Undang Republik Indonesia Nomor 36 Tahun 2009 tentang Khasiat Obat Tradisional. [serial online]. 2009. [Diakses tanggal 30 Juni 2018]. Available at http://www.jdih.kemenkeu.go.id/fulltext/ 2009/36 TAHUN 2009 UU.htm

5. Gunarto A. Menata Tanaman Obat Keluarga (TOGA) Di Pekarangan Rumah. Prosiding Seminar Nasional dan Pameran Perkembangan Teknologi Tanaman Obat Dan Aromatik. [serial online]. 2007. [Diakses tanggal 10 Juni 2018] Available at http://biodiversitas.mipa.uns.ac.id/M/M0 108/M010823.pdf.

6. Rahayu T. Budidaya Tanaman Khasiat Obat dan Prospek Pengembangan. Agronomika 2007:4 (2):17-20. [Serial tanaman herbal yang ada di sekitar kita dengan sebaik mungkin.

Online] [Diakses tanggal 25 Juni 2018] Available at http://biodiversitas.mipa.uns.ac.id/M/M0 108/M010823.pdfMu

7. Sawwir, B. Peran Kader dan Tenaga Kesehatan Dalam Pemanfaatan Apotek Hidup di Desa Kadidi Kabupaten Sidrap. Parepare: FKM UMPAR; 2011.

8. Rusmi. Ilmu Perilaku M.A. 104. Jakarta: CV Sagung Seto; 2009.

9. Notoatmodjo S. Promosi Kesehatan dan Perilaku Kesehatan. Jakarta: Rineka Cipta; 2012. [serial online] [Diakses tanggal 30 Juni 2018] Available at http://www.bukabuku.com/browses/prod uct/9789790980327/promosi-kesehatandan perilaku-kesehatan-(edisirevisi).html.

10.Asriullah Jabbar, Musdalipah, Andi Nurwati. Studi Pengetahuan, Sikap dan Tindakan Terhadap Penggunaan Obat Tradisional di Desa Sabi-Sabila Kecamatan Mowewe Kabupaten Kolaka Timur. Majalah Farmasi, Sains, dan Kesehatan ISSN 2442-9791. 2016: 3(1): 19-22. [serial online] [Diakses tanggal 30 Agustus 2018] Available at http://ojs.uho.ac.id/index.php/pharmauho/ article/view/3448. 


\section{LAMPIRAN}

Tabel 1. Distribusi karakteristik responden berdasakan umur, pendidikan dan pekerjaan kader Posyandu di Desa Karrang Kabupaten Enrekang

\begin{tabular}{llll}
\hline Karakteristik & Frekuensi (f) & Persentase $(\%)$ \\
\hline Umur (Tahun) & & & \\
$25-30$ & 5 & 33,3 & \\
$31-36$ & 3 & 20,0 & \\
$37-42$ & 5 & 33,3 & \\
$43-48$ & 2 & 13,3 & \\
\hline Total & 15 & & 100,0 \\
\hline Pendidikan & & & \\
SD & 3 & 20,0 & \\
SMP & 4 & 26,7 & \\
SMA & 7 & 46,7 & \\
S1 & 1 & 6,7 & \\
\hline Total & 15 & & 100,0 \\
\hline Pekerjaan & & & \\
PNS & 1 & 6,7 & \\
Wiraswasta & 5 & 33,3 & \\
IRT & 9 & 60,0 & \\
\hline Total & 15 & & 100,0 \\
\hline
\end{tabular}

Tabel 2. Distribusi karakteristik responden berdasarkan kriteria sikap kader dalam pemanfaatan apotek hidup di Desa Karrang Kecamatan Cendana Kabupaten Enrekang

\begin{tabular}{llll}
\hline Sikap & Frekuensi (f) & Persentase (\%) \\
\hline Baik & 13 & 86,7 & \\
Cukup & 2 & 13,3 & \\
Kurang & 0 & 0,0 & \\
\hline Total & 15 & & 100,0 \\
\hline
\end{tabular}

Tabel 3. Distribusi karakteristik responden berdasarkan kriteria tindakan kader dalam pemanfaatan apotek hidup di Desa Karrang Kecamatan Cendana Kabupaten Enrekang

\begin{tabular}{llll}
\hline Tindakan & Frekuensi (f) & Persentase (\%) \\
\hline Baik & 14 & 93,3 & \\
Cukup & 1 & 6,7 & \\
Kurang & 0 & 0,0 & \\
\hline Total & 15 & & 100,0 \\
\hline
\end{tabular}

